\title{
Injectable Fillers: Review of Material and Properties
}

\author{
Natalie Huang Attenello, MD ${ }^{2}$ Corey S. Maas, MD, FACS ${ }^{1,2}$ \\ ${ }^{1}$ Department of Facial Plastic and Reconstructive Surgery, University \\ of California, San Francisco, California \\ Address for correspondence Corey S. Maas, The Maas Clinic, 2400 Clay \\ Street, San Francisco, CA 94115 (e-mail: drmaas@maasclinic.com).
}

2 Department of Aesthetic and Facial Plastic Surgery, The Maas Clinic, San Francisco, California

Facial Plast Surg 2015;31:29-34.

\begin{abstract}
Keywords

- soft tissue fillers

- hyaluronic acid

- calcium hydroxylapatite

- poly--lactic acid

- polymethylmethacrylate

With an increasing understanding of the aging process and the rapidly growing interest in minimally invasive treatments, injectable facial fillers have changed the perspective for the treatment and rejuvenation of the aging face. Other than autologous fat and certain preformed implants, the collagen family products were the only Food and Drug Administration approved soft tissue fillers. But the overwhelming interest in soft tissue fillers had led to the increase in research and development of other products including bioengineered nonpermanent implants and permanent alloplastic implants. As multiple injectable soft tissue fillers and biostimulators are continuously becoming available, it is important to understand the biophysical properties inherent in each, as these constitute the clinical characteristics of the product. This article will review the materials and properties of the currently available soft tissue fillers: hyaluronic acid, calcium hydroxylapatite, poly---lactic acid, polymethylmethacrylate, and autologous fat (and aspirated tissue including stem cells).
\end{abstract}

Minimally invasive procedures have revolutionized the treatment paradigm for facial rejuvenation and may very well be one of the most significant changes in the recent history for facial plastic surgery. Initially utilized for the treatment of fine lines and wrinkles, the concept of fillers has expanded to include correction of volume loss and augmentation of the aging face. Since bovine collagen was introduced as the first injectable filler in the early 1970s, several other products have been developed for soft tissue augmentation ranging from both synthetic materials to autologous tissue. The ideal soft tissue filler is one that is effective, nonimmunogenic, nontoxic, noncarcinogenic, nonmigratory, easily applied, nonpalpable, painless, and long lasting. ${ }^{1}$ Currently available injectable fillers can be broadly classified into the following three different categories: hyaluronic acid (HA) derivatives, synthetic fillers, and autologous fat. This article reviews the varying properties and materials inherent in the currently available injectable fillers (-Table 1).

\section{Historical Background}

The utility of facial fillers traces back to the 19th century when autologous fat was first described as a soft tissue filler for cosmetic deformity by the German physician, Dr. Franz Neuber. ${ }^{2}$ This was later replaced by paraffin in the early $1900 \mathrm{~s}$ but was soon abandoned after reports of embolization, granuloma formation, and migration. ${ }^{3}$ In the mid-20th century, a shift was seen toward purified synthetic polymers in the form of injectable silicone. Although seemingly promising at first, the Food and Drug Administration (FDA) eventually banned this for similar complications of granuloma formation. ${ }^{4}$ Although, microdroplet injection of limited amounts of silicone material is still used today as an off-label use for silicone that is FDA approved for ocular injections. ${ }^{5-7}$ Teflon, a synthetic polytetrafluoroethylene polymer, was next tested as a soft tissue filler, but it was quickly abandoned because of the inflammatory reaction and injection difficulty that was experienced. ${ }^{8}$ Until the early 1980 s, none of the previously
Issue Theme Management of Facial Volume; Guest Editors, Edward D. Buckingham, MD, and Mark Glasgold, MD
Copyright $\odot 2015$ by Thieme Medical Publishers, Inc., 333 Seventh Avenue, New York, NY 10001, USA. Tel: +1(212) 584-4662.
DOI http://dx.doi.org/ 10.1055/s-0035-1544924. ISSN 0736-6825. 
Table 1 Comparison of soft tissue fillers

\begin{tabular}{|c|c|c|c|c|c|}
\hline & Filler & Manufacturer & Composition & Needle size & Depth \\
\hline \multirow[t]{5}{*}{ Hyaluronic acid } & Restylane & $\begin{array}{l}\text { Galderma, Ft. } \\
\text { Worth, TX }\end{array}$ & $\begin{array}{l}20 \mathrm{mg} / \mathrm{mL} \text { hyaluronic } \\
\text { acid; } 400 \mu \mathrm{m} \text { particle } \\
\text { size }\end{array}$ & 29-30 gauge & Mid-to-deep dermis \\
\hline & Perlane & $\begin{array}{l}\text { Galderma, Ft. } \\
\text { Worth, TX }\end{array}$ & $\begin{array}{l}20 \mathrm{mg} / \mathrm{mL} \text { hyaluronic } \\
\text { acid; } 750-1,000 \mu \mathrm{m} \\
\text { particle size }\end{array}$ & 27-29 gauge & $\begin{array}{l}\text { Deep dermis, } \\
\text { superficial subcutis }\end{array}$ \\
\hline & Juvéderm XC & $\begin{array}{l}\text { Allergan, Inc, } \\
\text { Irvine, CA }\end{array}$ & $\begin{array}{l}24 \mathrm{mg} / \mathrm{mL} \text { with } 0.3 \% \\
\text { lidocaine }\end{array}$ & 27 gauge & Mid-to-deep dermis \\
\hline & Juvéderm Voluma & $\begin{array}{l}\text { Allergan, Inc, } \\
\text { Irvine, CA }\end{array}$ & $\begin{array}{l}20 \mathrm{mg} / \mathrm{mL} \text { with } 0.3 \% \\
\text { lidocaine }\end{array}$ & 27 gauge & $\begin{array}{l}\text { Deep (subcutane- } \\
\text { ous, } \\
\text { supraperiosteal) }\end{array}$ \\
\hline & Belotero & $\begin{array}{l}\text { Merz North America, } \\
\text { Greensboro, NC }\end{array}$ & $22.5 \mathrm{mg} / \mathrm{mL}$ & 30 gauge & Mid-to-deep dermis \\
\hline \multirow[t]{3}{*}{ Synthetic fillers } & Radiesse & $\begin{array}{l}\text { BioForm Medical, San } \\
\text { Mateo, CA }\end{array}$ & $\begin{array}{l}30 \% \text { calcium hydroxyl- } \\
\text { apatite microspheres/ } \\
70 \% \text { carrier gel }\end{array}$ & 25-27 gauge & Subdermal \\
\hline & Sculptra & $\begin{array}{l}\text { Dermik Laboratories, } \\
\text { Berwyn, PA }\end{array}$ & $\begin{array}{l}367.5 \mathrm{mg} \text { powder of } \\
\text { poly---lactic acid } \\
\text { microspheres }\end{array}$ & 26 gauge & Deep dermis \\
\hline & ArteFill & $\begin{array}{l}\text { Suneva Medical, San } \\
\text { Diego, CA }\end{array}$ & $\begin{array}{l}20 \% \text { polymethylme- } \\
\text { thacrylate suspended } \\
\text { in } 80 \% \text { solution with } \\
3.5 \% \text { bovine collagen } \\
\text { and } 0.3 \% \text { lidocaine }\end{array}$ & 26 gauge & $\begin{array}{l}\text { Dermal-subdermal } \\
\text { junction }\end{array}$ \\
\hline Autologous fat & Autologous fat & Autologous & Liposuctioned fat & $\begin{array}{l}18 \text { gauge nee- } \\
\text { dle with blunt } \\
\text { cannula }\end{array}$ & Subcutaneous \\
\hline
\end{tabular}

attempted facial fillers had received FDA approval until the bovine collagen, Zyderm (Inamed Corp., Santa Barbara, CA) was approved in 1981. The approval of Zyderm led to widespread research and development of other fillers including alloplastic and implantable materials as well as the renewed interest and utilization of autologous fat. ${ }^{9}$ Even with an increase in research, though, bovine collagen was the only FDA approved filler for the next two decades until 2003 when the FDA approved the first HA dermal filler (Restylane; Galderma, Ft. Worth, TX). Since this approval, the last decade has seen a dramatic increase in the number of FDA approved facial fillers in response to the growing popularity of minimally invasive facial rejuvenation procedures. Over 2 million soft tissue filler procedures were performed in the United States in 2012. ${ }^{10}$

\section{Hyaluronic Acid Derivatives}

HA is a naturally occurring glycosaminoglycans composed of D-glucuronic acid and $N$-acetyl-D-glucosamine found in the dermis. At physiologic $\mathrm{pH}$, HA has excellent biocompatibility as it is anionic and thus binds to water extensively where $1 \mathrm{~g}$ $\mathrm{HA}$ can bind up to $6 \mathrm{~L}$ water. ${ }^{11}$ Because of this intrinsic solubility, although, it is rapidly cleared when injected into the normal skin-a characteristic that should be carefully controlled if utilized as a dermal filler. ${ }^{11-14}$ Therefore, chemical modification to the carboxyl acid group, and cross-linking with dialdehydes and disulfides, was necessary to change its mechanical properties-such as gel firmness and half-life of the HA product (- Figs. 1 and 2). ${ }^{11,15}$ The different compositions of the chemically modified HA fillers are at the discretion of the manufacturer and thus create variations amongst the HA products as fillers.

The concentration of HA in the filler differs with each manufacturer and is typically listed as the total amount of $\mathrm{HA}$ (soluble and insoluble $\mathrm{HA}, \mathrm{mg} / \mathrm{mL}$ ) found in the filler. ${ }^{12}$ It is important to understand that only the cross-linked HA, or the more insoluble HA, functions as the dermal filler by resisting degradation and providing more longevity in the dermis. The listed soluble-free HA, or unmodified HA, are usually byproducts of their chemical modifications and will quickly be metabolized given their solubility.

Most HAs are viscoelastic and this is measured with the complex modulus, which is the sum of the elastic modulus $\left(G^{\prime}\right)$ with the viscous modulus $\left(G^{\prime \prime}\right)$. The elastic modulus $\left(G^{\prime}\right)$ is used most commonly to characterize the firmness of the gel and measures the resistance of a material to deformation-the stiffer the material then the higher the $\mathrm{G}^{\prime} .^{12,16}$ This is determined by the degree and strength of interaction in the crosslinking HA as well as the HA concentration. Clinically, this becomes important because gels with a higher $G^{\prime}$ will have better resistance to the dynamic forces incurred with facial muscle movement providing long lasting support and volumization, this is ideal for areas such as the nasolabial folds and marionette lines. ${ }^{12}$ One should be cognizant, although, that gels with a higher $G^{\prime}$ can cause visible small blue papules or 


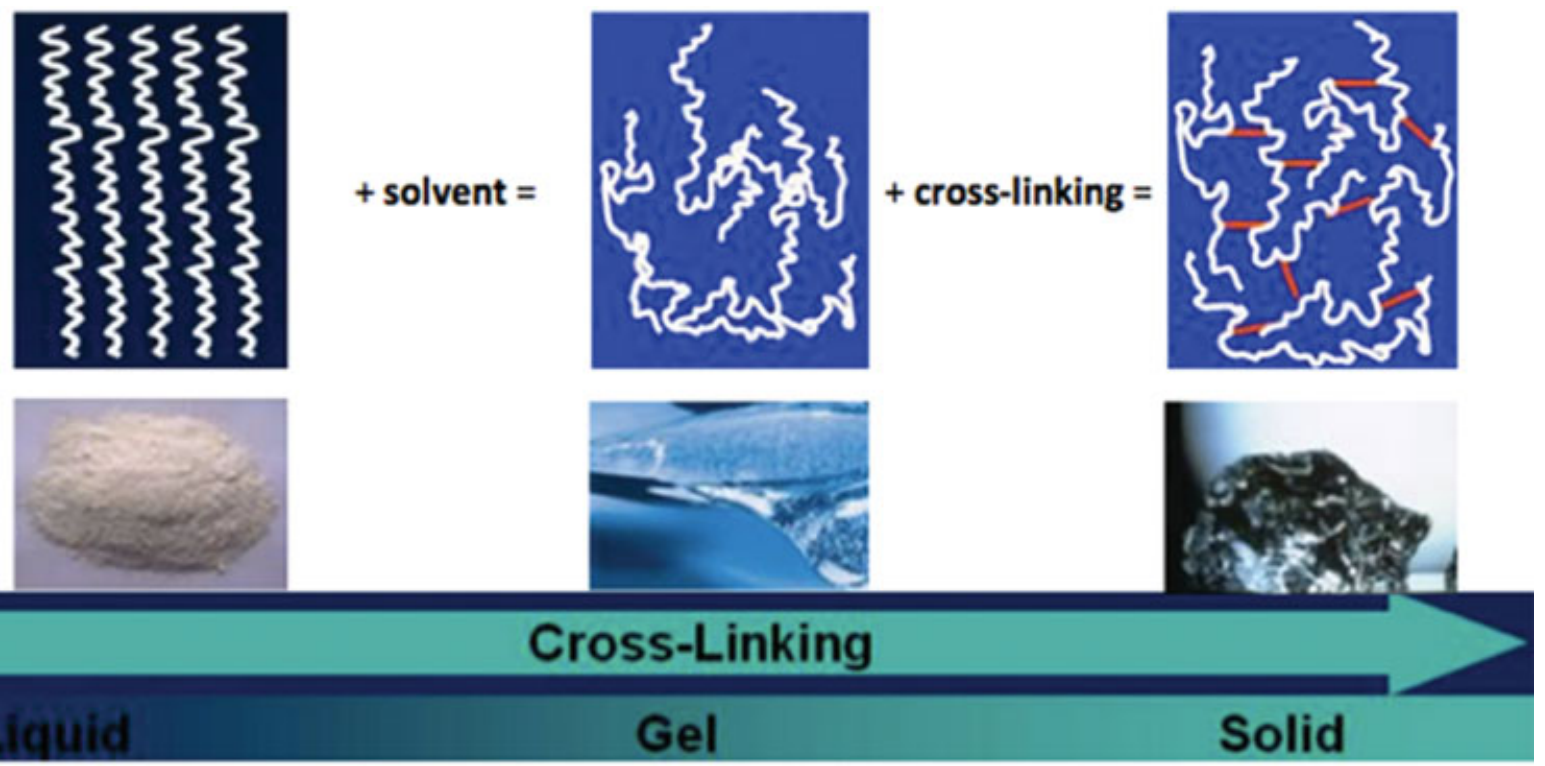

Fig. 1 Cross-linking schematic of hyaluronic acid. (Courtesy of Galderma, Ft. Worth, TX.)

nodules (Tyndall effect) if injected superficially in the skin. ${ }^{17,18}$ In contrast, in areas that are more static or with superficial wrinkles, resistance to deformation by muscle movement is less critical and gels with lower $G^{\prime}$ are better utilized. These gels are also better suited for areas that need more softness, such as the lips. ${ }^{12}$ Although all HA gels vary in elastic modulus, even the ones with the highest $G^{\prime}$ are much softer than the elastic modulus of human dermis, which has $\mathrm{G}^{\prime}$ in the 3-MPa range. ${ }^{12,19}$

Swelling varies among products and manufacturers and can partially be attributed to the molecular characteristic of HA-the concentration, amount of cross-linking, and the products used to hydrate the gel. ${ }^{12}$ A gel that is fully hydrated will not swell any further upon injection into the dermis as they have already reached their hydration capacity. Conversely, nonequilibrium gels have a tendency to swell after injection and thus one must consider underfilling when using these types of gels. ${ }^{12}$

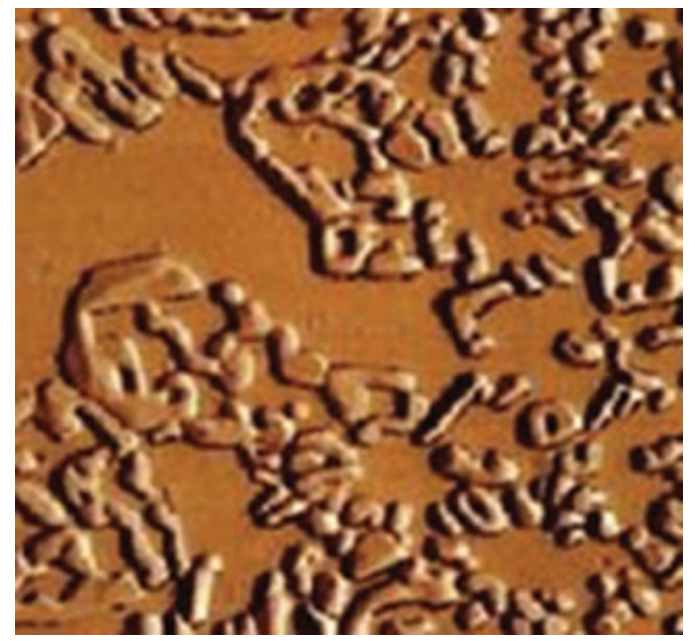

Fig. 2 Cross-linking of hyaluronic acid. (Courtesy of Galderma, Ft. Worth, TX.)
The particle size and the range of distribution of particle size are another important component for the composition of $\mathrm{HA}$ gels as this will influence the extrusion force needed for injection. A larger gel particle will be more difficult to inject through a small bore needle and a more narrow range of distribution of particle size can decrease interruptions in the flow of particle extrusion, as uniformity is ideal to provide better control of gel placement. ${ }^{12}$ The $\mathrm{G}^{\prime}$ also affects the ability to inject the product through a small bore needle as firm gels with a higher resistance to deformation must be sized as a smaller particle and have a narrow particle size range to facilitate particle extrusion. Whereas softer gels with a low $\mathrm{G}^{\prime}$ can have a broader range of particle size because these gels can be easily deformed as they pass through the needle. ${ }^{12}$

A unique characteristic of HA is its reversibility via enzymatic digestion with injection of hyaluronidase. ${ }^{20}$ This naturally occurring enzyme is FDA approved as a temporary drug dispersion agent by cleaving HA between $\mathrm{C} 1$ of an $\mathrm{N}$-acetylglucosamine moiety and $\mathrm{C} 4$ of a glucuronic acid moiety. ${ }^{21}$ Thus, its function as a reversal agent for HA is actually offlabel, but it has been utilized commonly for reversal of HA fillers. Because of the varying biochemical compositions of the different HA products, it should be noted that each product may respond differently to hyaluronidase. ${ }^{21}$

Distributed by the same manufacturer, both Restylane and Perlane (Galderma, Ft. Worth, TX) have similar qualities and are considered biphasic gels because they consist of particles suspended in a liquid (-Table 1). These HA molecules are cross-linked with 1,4-butanediol diglycidyl ether, which will decrease the rate of degradation as well as increase the surface area of the molecule. ${ }^{11}$ Restylane is a non-animalstabilized HA filler introduced in 1996 derived from the fermentation of Streptococcus species and has $20 \mathrm{mg} / \mathrm{mL}$ of $\mathrm{HA}$ with the average particle size of $400 \mu \mathrm{m} .{ }^{11}$ Perlane is similar to Restylane but has a larger particle size (range, 750$1,000 \mu \mathrm{m}$ ) and a decrease in surface area and thus contains less gel beads, 8,000 gel beads/mm, compared with Restylane 
which contains 100,000 gel beads/mm. ${ }^{11,22}$ Theoretically, this can decrease its rate of degradation and increase its duration of effect. ${ }^{11}$ Because Perlane has a larger particle size, it is better suited for deeper levels of injection such treatment for deep cutaneous depressions. Perlane also needs to be injected through a 27-gauge needle compared with a 30-gauge needle used for Restylane, which may cause slightly more pain upon injection. ${ }^{11,23}$ Restylane, in contrast, can be injected superficially given its smaller particle size, although like all HA fillers, Restylane does create Tyndall effect in standard concentrations when used in the papillary dermis. ${ }^{11,17}$ Overall, both Restylane and Perlane have a higher $\mathrm{G}^{\prime}$, hence are more firm with less spreading of product and is therefore better suited for placement in the subdermal level, particularly in the midface. $^{20}$ In a real-time ultrasound study, Micheels et al demonstrated that Restylane, with its high viscosity and least tendency to spread, was distributed fairly evenly in welldefined boluses within the deep reticular dermis. ${ }^{20,24}$

Juvéderm (Allergan Inc, Irvine, CA) is currently available in two types: Juvéderm XC and Juvéderm Voluma with a HA concentration of 24 and $20 \mathrm{mg} / \mathrm{mL}$, respectively (-Table 1). Unlike Restylane and Perlane, the Juvéderm products do not get passed through sizing screens via sieves and instead are not quantified by their particle size, but are considered "cohesive molecules" of cross-linked HA. ${ }^{20,25}$ Thus, manufactured using the proprietary Hylacross technology, Juvéderm products are considered a monophasic gel. Both of the Juvéderm products have an intermediate $G^{\prime}$ and viscosity, which leads to a higher likelihood of spreading after implantation and a softer feel. ${ }^{20}$ Because Juvéderm XC has a lower $G^{\prime}$ and viscosity than Juvéderm Voluma, it is ideal for areas where palpability is less desirable, and a small amount of product spreading may be beneficial, such as the lips. ${ }^{20,26}$ In addition, because Juvéderm XC is less dense, it is optimal for medium-depth wrinkle correction, such as forehead wrinkles, glabellar lines, nasolabial folds, and moderate nasal furrows. ${ }^{11}$ Juvéderm Voluma, FDA approved in October 2013, was biochemically modified to be the first and only product for correction of volume loss in the midface. By combining a low-molecular-weight ( $<1 \mathrm{mDa}$ ) and high-molecular-weight ( $>1 \mathrm{mDa}$ ) HA, this created an increase in covalent bonding to the cross-linking agent which increased the $\mathrm{G}^{\prime}{ }^{27}$ Combined with a higher $G^{\prime}$ and a low-swelling capacity, this made Juvéderm Voluma ideal for long-term deep soft tissue volume restoration, potentially lasting up to 2 years. ${ }^{27}$

Belotero (Merz North America, Greensboro, NC) was FDA approved in 2011 for treatment of moderate-to-severe nasolabial folds and wrinkles. ${ }^{28}$ Belotero has a higher concentration of non-cross-linked HA and is considered polydensified as the cross-linking is not uniform throughout. ${ }^{29}$ This results in a low viscosity and the lowest $G^{\prime}$ of the currently available HA fillers. ${ }^{28}$ With these properties, Belotero is utilized mainly in areas for superficial injection in the dermis or subdermal plane as it is a softer product (due to the low $\mathrm{G}^{\prime}$ ) that allows it to spread more evenly given its low viscosity. $^{29}$ In a histologic evaluation, Flynn et al observed Belotero diffuse into the dermis (except the papillary dermis) evenly and widely. ${ }^{30}$ Clinically, Belotero is useful for very fine lines such as the forehead, vermillion border, and in the tear trough. $^{29}$

\section{Synthetic Fillers}

\section{Radiesse}

Radiesse (Merz North America, Greensboro, NC) is a synthetic, semisolid filler composed of $30 \%$ calcium hydroxylapatite and $70 \%$ carrier gel that was initially approved in 2006 for the treatment of facial wrinkles and folds as well as HIV-associated facial atrophy and then later approved in 2009 for more cosmetic applications. It is considered a long-lasting, nonpermanent filler that is highly biocompatible given that it is identical to the physiologic mineral component found in human bone and teeth. ${ }^{23}$ Because of this, Radiesse has no antigenicity and thus provokes a little immune response.

The calcium hydroxylapatite (CaHA) microspheres are suspended in the carrier gel composed of sodium carboxymethylcellulose, water, and glycerin mix and this allows the particles to be easily delivered upon injection. Each CaHA particle size is between 25 and $45 \mu \mathrm{m}$, and therefore should be injected with a 25- to 27-gauge needle (-Table 1). After injection, the carrier gel that fills the interstitial space eventually dissipates and is replaced with soft tissue growth with the CaHA acting as a scaffold. ${ }^{31,32}$

Because Radiesse is mostly injected subdermally near or well below the dermal-subcutaneous junction, it is not a true filler. ${ }^{32}$ On injection, it provides a 1:1 level of correction, so over injection is not required. Injection too superficially can lead to visibility of the white material and nodularity and too deep of placement may require more material for adequate correction. ${ }^{33}$ Because of its opaque color, CaHA is less ideal for areas such as the lips as opposed to certain HAs, which are translucent. In a study comparing the rheologics of the different soft tissue fillers, Radiesse was in the high-viscosity and high-elasticity $\left(G^{\prime}\right)$ group and Radiesse with $0.3 \%$ lidocaine was in the medium group. ${ }^{34}$ These properties can be translated into clinical advantages and disadvantages. Studies have supported this notion as shown on a split-face study that less Radiesse (a very high viscosity and high elasticity filler) was required for nasolabial fold correction than a soft tissue filler with a lower viscosity and elasticity. ${ }^{35,36}$ The addition of lidocaine to CaHA modestly dilutes the elasticity and viscosity of the product, which can be advantageous in certain clinical situations, such that the extrusion force is reduced and CaHA is easier to spread and less palpable but still providing adequate lift. ${ }^{34}$

\section{Sculptra}

Polylactic acids were originally synthesized by French chemists in 1954 from the $\alpha$-hydroxy-acid family and have been used safely as suture materials, resorbable plates, and screws in orthopedic, neurologic, and craniofacial surgery. ${ }^{37}$ Approved by the FDA in 2004 for soft tissue restoration in lipoatrophy in HIV patients, this was later expanded to include cosmetic applications in 2009 as Sculptra (Dermik Laboratories, Berwyn, PA). Sculptra functions as more than just a soft tissue filler, but as a biostimulator by stimulating the production and vascularization of collagen. ${ }^{38,39}$ Studies 
have demonstrated an increase in skin thickness because of collagen formation as early as 6 weeks after injection, which remained for up to 96 weeks. ${ }^{38,40}$ Sculptra comes as a powder of poly-L-lactic acid microspheres mixed with sodium carboxymethylcellulose mannitol, and sterile water for injection. The microspheres range from 1 to $63 \mu \mathrm{m}$ in diameter that eventually gets dissolved into carbon dioxide and water. Initial studies showed a high rate of nodule formation, especially in patients with severe soft tissue or lipoatrophy, although these nodules resolved spontaneously and was attributed to product placement too superficially or in the perioral and periocular region. 4,41

Sculptra was approved in treatment of shallow to deep nasolabial folds, facial wrinkles and lines, and improvement of contour deficiencies with placement recommended subcutaneously. ${ }^{4}$ Because results rely on new collagen formation after several weeks, it will not have instantaneous results and thus can be used in conjunction with other fillers such as HA or CaHA. ${ }^{38}$

\section{ArteFill}

ArteFill (Suneva Medical, San Diego, CA) is a third generation polymethylmethacrylate (PMMA) and collagen filler that was first developed over 20 years ago in Germany as Arteplast and its second generation successor, Artecoll. Although both fillers had adequate soft tissue filler capabilities, they also had an unacceptable rate of granuloma formation and were not approved by the FDA. Further research elucidated that PMMA microsphere size was critical to avoid phagocytosis by macrophages and giant cell formation resulting in inflammation. Associated observations suggested that small PMMA microspheres, less than $20 \mu \mathrm{m}$ in diameter, provoked a foreign body response. ${ }^{42,43}$ Addressing these observations, the synthetic formulation was changed and ArteFill consisted of $20 \%$ PMMA microspheres, 30 to $50 \mu \mathrm{m}$ in diameter, which is suspended in $80 \%$ of mostly denatured bovine collagen. Because of the bovine collagen, a skin test is needed because of a $3 \%$ prevalence of hypersensitivity. ${ }^{38,44}$ With a dramatic decrease in granuloma formation from $2.5 \%$ with Arteplast to less than $0.01 \%$ with ArteFill and a better safety profile, ArteFill was approved for treatment of the nasolabial folds in $2006 .{ }^{45}$

ArteFill is also a collagen production stimulator. ${ }^{42}$ Because ArteFill has a smooth, round surface and is suspended in collagen, it allows tissue ingrowth into the interstitial space around the microspheres. This decreases the displacement of the filler, which also increases the volume. The resultant increase in volume is 20\% PMMA and $80 \%$ autologous connective tissue. ${ }^{38,45}$ Because the microspheres are too big for degradation by phagocytosis, they are permanent microspheres and cannot be reversed. Given the irreversibility and the risk of nodularity around the lip and eyes, ArteFill is not recommended for these areas.

\section{Autologous Fat Injection}

Autologous fat has many characteristics of an ideal filler-it is biocompatible, inexpensive, readily available, easily acquired, and noncarcinogenic; but the long-term results of lipotransfer are still variable and unpredictable. ${ }^{46}$ The first autologous fat transfer was performed by Dr. Franz Neuber in 1893 to fill scars on the forearm. In the early 1900s, others saw some improvement in facial contour after the placement of fat, though the results were overall considered unreliable. ${ }^{23,46,47}$ In 1950, Peer reported an average loss of $45 \%$ in the weight of the free fat implant by 1 year and this emphasized the importance of a well-vascularized recipient site. ${ }^{48}$ It was not until the 1970s, at the advent of liposuction, that renewed interest in autologous fat for micro-lipoinjection became popular as a means for esthetic correction of facial volume loss. $^{23,49}$ In addition, autologous fat spurred interest into other autologous donor material, and it should be noted that platelet-rich plasma has been utilized via a proprietary system and injected into the dermis showing promising results when used for the nasolabial folds, acne scars, or superficial rhytids. ${ }^{50,51}$

Adipose tissue is composed of adipocytes contained within a matrix of connective tissue and a small vascular pedicle that supplies each fat cell, also known as "lipid lobule." ${ }^{46}$ There have been studies proposing mesenchymal adult stem cells that may differentiate into adipocytes, though this warrants further research. ${ }^{52}$

A blunt-tipped microcannula is used to harvest fat from various regions of the body, which then gets purified from the serosanguinous debris. ${ }^{23}$ The harvested fat is then prepared for facial injection and overcorrection by 30 to $50 \%$ is recommended given the amount of resorption. A biopsy of an injected tissue showed fibrotic tissue as a result of an inflammatory reaction as possible mechanism for facial volume restoration. ${ }^{23}$ Fat injection may be used to address multiple areas including the nasolabial and melolabial folds, lips, and hemifacial atrophy.

\section{Conclusion}

The development of facial fillers is a constantly advancing field with the goal of refining products to maximize the efficacy while minimizing the adverse effects. With the ability to manipulate the biochemical compositions of the inherent characteristics of the fillers, it is becoming apparent that no singular filler can treat the entire face. Instead, different fillers are emerging as unique products best suited for certain regions given the varying characteristics and esthetic needs of the face.

\section{References}

1 Nettar K, Maas C. Facial filler and neurotoxin complications. Facial Plast Surg 2012;28(3):288-293

2 Neuber F. Fat grafting. Cuir Kongr Verh Otsum Ges Chir 1893;20:66

3 Ersek RA, Beisang AA III. Bioplastique: a new biphasic polymer for minimally invasive injection implantation. Aesthetic Plast Surg 1992;16(1):59-65

4 Kontis TC. Contemporary review of injectable facial fillers. JAMA Facial Plast Surg 2013;15(1):58-64

5 Benedetto AV, Lewis AT. Injecting 1000 centistoke liquid silicone with ease and precision. Dermatol Surg 2003;29(3):211-214

6 Orentreich DS. Liquid injectable silicone: techniques for soft tissue augmentation. Clin Plast Surg 2000;27(4):595-612

7 Webster RC, Gaunt JM, Hamdan US, Fuleihan NS, Smith RC. Injectable silicone for facial soft-tissue augmentation. Arch Otolaryngol Head Neck Surg 1986;112(3):290-296 
8 Landman MD, Strahan RW, Ward PH. Chin augmentation with polytef paste injection. Arch Otolaryngol 1972;95(1):72-75

9 Miller PJ, Levine J, Ahn MS, Maas CS, Constantinides M. Softform for facial rejuvenation: historical review, operative techniques, and recent advances. Facial Plast Surg 2000;16(1):23-28

10 ASPS. Available at: http://www.plasticsurgery.org. Accessed August 1, 2014

11 Maas CS, Bapna S. Pins and needles: minimally invasive office techniques for facial rejuvenation. Facial Plast Surg 2009;25(4): 260-269

12 Kablik J, Monheit GD, Yu L, Chang G, Gershkovich J. Comparative physical properties of hyaluronic acid dermal fillers. Dermatol Surg 2009;35(Suppl 1):302-312

13 Laurent UBG, Reed RK. Turnover of hyaluronan in the tissues. Adv Drug Deliv Rev 1991;7:237-256

14 Almond A. Hyaluronan. Cell Mol Life Sci 2007;64(13):1591-1596

15 Lapcík LJr, Lapcík L, De Smedt S, Demeester J, Chabrecek P. Hyaluronan: Preparation, Structure, Properties, and Applications. Chem Rev 1998;98(8):2663-2684

16 Edsman K, Nord LI, Ohrlund A, Lärkner H, Kenne AH. Gel properties of hyaluronic acid dermal fillers. Dermatol Surg 2012;38(7, Pt 2): 1170-1179

17 Fabi SG, Champagne JP, Nettar KD, Maas CS, Goldman MP. Efficacy and safety of and patient satisfaction with injectable hyaluronic acid with $0.3 \%$ lidocaine hydrochloride for the treatment of superficial perioral lines or superficial lateral canthal lines. Dermatol Surg 2013;39(11):1613-1620

18 Maas CS. Botulinum neurotoxins and injectable fillers: minimally invasive management of the aging upper face. Facial Plast Surg Clin North Am 2006;14(3):241-245

19 Gennisson JL, Baldeweck T, Tanter M, et al. Assessment of elastic parameters of human skin using dynamic elastography. IEEE Trans Ultrason Ferroelectr Freq Control 2004;51(8):980-989

20 Sundaram H, Cassuto D. Biophysical characteristics of hyaluronic acid soft-tissue fillers and their relevance to aesthetic applications. Plast Reconstr Surg 2013;132(4, Suppl 2):5S-21S

21 Rao V, Chi S, Woodward J. Reversing facial fillers: interactions between hyaluronidase and commercially available hyaluronicacid based fillers. J Drugs Dermatol 2014;13(9):1053-1056

22 Brandt FS, Cazzaniga A. Hyaluronic acid fillers: Restylane and Perlane. Facial Plast Surg Clin North Am 2007;15(1):63-76, vii

23 Ali MJ, Ende K, Maas CS. Perioral rejuvenation and lip augmentation. Facial Plast Surg Clin North Am 2007;15(4):491-500, vii

24 Micheels P, Besse S, Flynn TC, Sarazin D, Elbaz Y. Superficial dermal injection of hyaluronic acid soft tissue fillers: comparative ultrasound study. Dermatol Surg 2012;38(7, Pt 2):1162-1169

25 Stocks D, Sundaram H, Michaels J, Durrani MJ, Wortzman MS, Nelson DB. Rheological evaluation of the physical properties of hyaluronic acid dermal fillers. J Drugs Dermatol 2011;10(9):974-980

26 Fagien S, Maas C, Murphy DK, Thomas JA, Beddingfield FC III; Juvéderm Lips Study Group. Juvederm ultra for lip enhancement: an open-label, multicenter study. Aesthet Surg J 2013;33(3):414-420

27 Callan P, Goodman GJ, Carlisle I, et al. Efficacy and safety of a hyaluronic acid filler in subjects treated for correction of midface volume deficiency: a 24 month study. Clin Cosmet Investig Dermatol 2013;6:81-89

28 Hevia O, Cohen BH, Howell DJ. Safety and efficacy of a cohesive polydensified matrix hyaluronic acid for the correction of infraorbital hollow: an observational study with results at 40 weeks. J Drugs Dermatol 2014;13(9):1030-1036

29 Lorenc ZP, Fagien S, Flynn TC, Waldorf HA. Clinical application and assessment of Belotero: a roundtable discussion. Plast Reconstr Surg 2013;132(4, Suppl 2):69S-76S

30 Flynn TC, Sarazin D, Bezzola A, Terrani C, Micheels P. Comparative histology of intradermal implantation of mono and biphasic hyaluronic acid fillers. Dermatol Surg 2011;37:1-7
31 Berlin AL, Hussain M, Goldberg DJ. Calcium hydroxylapatite filler for facial rejuvenation: a histologic and immunohistochemical analysis. Dermatol Surg 2008;34(Suppl 1):S64-S67

32 Jacovella PF. Use of calcium hydroxylapatite (Radiesse) for facial augmentation. Clin Interv Aging 2008;3(1):161-174

33 Ahn MS. Calcium hydroxylapatite: Radiesse. Facial Plast Surg Clin North Am 2007;15(1):85-90, vii

34 Sundaram H, Voigts B, Beer K, Meland M. Comparison of the rheological properties of viscosity and elasticity in two categories of soft tissue fillers: calcium hydroxylapatite and hyaluronic acid. Dermatol Surg 2010;36(Suppl 3):1859-1865

35 Moers-Carpi M, Vogt S, Santos BM, Planas J, Vallve SR, Howell DJ. A multicenter, randomized trial comparing calcium hydroxylapatite to two hyaluronic acids for treatment of nasolabial folds. Dermatol Surg 2007;33(Suppl 2):S144-S151

36 Moers-Carpi MM, Tufet JO. Calcium hydroxylapatite versus nonanimal stabilized hyaluronic acid for the correction of nasolabial folds: a 12-month, multicenter, prospective, randomized, controlled, split-face trial. Dermatol Surg 2008;34(2):210-215

37 Weinkle SH. The Science of Dermal Fillers. Medscape Education Dermatology, 2010. Available at: www.medscape.org. Accessed August 1, 2014

38 Greco TM, Antunes MB, Yellin SA. Injectable fillers for volume replacement in the aging face. Facial Plast Surg 2012;28(1): 8-20

39 Gogolewski S, Jovanovic M, Perren SM, Dillon JG, Hughes MK. Tissue response and in vivo degradation of selected polyhydroxyacids: polylactides (PLA), poly(3-hydroxybutyrate) (PHB), and poly(3-hydroxybutyrate-co-3-hydroxyvalerate) (PHB/VA). J Biomed Mater Res 1993;27(9):1135-1148

40 Valantin MA, Aubron-Olivier C, Ghosn J, et al. Polylactic acid implants (New-Fill) to correct facial lipoatrophy in HIV-infected patients: results of the open-label study VEGA. AIDS 2003;17(17): 2471-2477

41 Lowe NJ, Maxwell CA, Lowe P, Shah A, Patnaik R. Injectable poly-llactic acid: 3 years of aesthetic experience. Dermatol Surg 2009;35 (Suppl 1):344-349

42 Lemperle G, Knapp TR, Sadick NS, Lemperle SM. ArteFill permanent injectable for soft tissue augmentation: I. Mechanism of action and injection techniques. Aesthetic Plast Surg 2010; 34(3):264-272

43 Lemperle G, Gauthier-Hazan N, Wolters M, Eisemann-Klein M, Zimmermann U, Duffy DM. Foreign body granulomas after all injectable dermal fillers: part 1 . Possible causes. Plast Reconstr Surg 2009;123(6):1842-1863

44 Haneke E. Polymethyl methacrylate microspheres in collagen. Semin Cutan Med Surg 2004;23(4):227-232

45 Lemperle G, Romano JJ, Busso M. Soft tissue augmentation with artecoll: 10-year history, indications, techniques, and complications. Dermatol Surg 2003;29(6):573-587, discussion 587

46 Jatana KR, Smith SP Jr. The scientific basis for lipotransfer: is it the ideal filler? Facial Plast Surg Clin North Am 2008;16(4):443-448, vi-vii

47 Coleman SR. Structural fat grafting: more than a permanent filler. Plast Reconstr Surg 2006;118(3, Suppl):108S-120S

48 Peer LA. Loss of weight and volume in human fat grafts: with postulation of a "cell survival theory". Plast Reconstr Surg 1950; 5:217-230

49 Illouz YG. The fat cell "graft": a new technique to fill depressions. Plast Reconstr Surg 1986;78(1):122-123

50 Sclafani AP. Safety, efficacy, and utility of platelet-rich fibrin matrix in facial plastic surgery. Arch Facial Plast Surg 2011;13(4):247-251

51 Sclafani AP. Platelet-rich fibrin matrix for improvement of deep nasolabial folds. J Cosmet Dermatol 2010;9(1):66-71

52 Ahn JM, Mao JJ. Adipose tissue engineering from adult human stem cells: a new concept in biosurgery. Facial Plast Surg 2010;26(5): 413-420 